\title{
Ectopic spleen in the pancreas of New Zealand White rabbits
}

\author{
Arabinda Adak, M. C. Prasad, P. S. Lonkar, U. M. Kapurkar, M. G. Brahmankar and M. V. Patel \\ Jai Research Foundation, \\ Near Daman Ganga Bridge, Off N.H.No 8, Valvada, Vapi, 396108, Gujarat, India \\ Corresponding author: Arabinda Adak, email: pathology@jrfonline.com \\ Received: 18-10-2012, Accepted: 09-11-2012, Published online: 29-03-2013
}

\section{How to cite this article:}

Adak A, Prasad MC, Lonkar PS, Kapurkar UM, Brahmankar MG and Patel MV (2013) Ectopic spleen in the pancreas of New Zealand White rabbits, Vet. World 6(6):360-362, doi: 10.5455/vetworld.2013.360-362

\begin{abstract}
Five cases (male-2, female-3) of ectopic splenic tissue in the pancreas of New Zealand White rabbits were recorded out of 144 rabbits aged between 16-25 weeks. The histomorphology of the ectopic splenic tissue compared well with normal spleen. The pancreatic parenchyma bearing ectopic splenic tissue did not exhibit any change or abnormality of pathological significance except less number of islets of Langerhans in comparison to other areas. The present cases were considered to be rare incidental finding and congenital in origin.
\end{abstract}

Keywords: ectopic spleen, histomorphology, New Zealand White rabbit, pancreas

\section{I ntroduction}

Ectopia is a rare congenital anomaly where a small mass of any histologically normal tissue is present at abnormal site e.g. parathyroid within thymus or pancreatic tissue in duodenum, liver and spleen [1, 2]. It is incidentally recorded only during histopathological interpretation among laboratory animals subjected to preclinical toxicological studies and other biological experiments [3]. Among human beings, intrapancreatic ectopic/accessory spleen is recorded during ultrasonography carried out in the diagnosis of various abdominal ailments or unselected autopsies $[4,5]$. There is paucity of information on various ectopic tissues in the pancreas of different laboratory animals. Five cases of ectopic splenic tissue in the pancreas of young New Zealand White rabbits of either sex encountered during routine histopathological observations excited us to put these cases on record.

\section{Materials and Methods}

One hundred and forty four (male -72 , female 72) New Zealand White rabbits aged between 16-25 weeks from various repeated dose toxicity studies conducted in compliance with the OECD (Organization for Economic Cooperation and Development) Principles of Good Laboratory Practice at Jai Research Foundation, Vapi (Gujarat) formed the materials for this study. Project proposals for these studies were duly approved by Institutional Animal Ethics Committee (IAEC), Jai Research Foundation and these studies were undertaken in compliance with the 'Guidelines for Laboratory Animals Facility' issued by the Committee for the Purpose of Control and Supervision of

This article is an open access article licensed under the terms of the Creative Commons Attribution License (http://creativecommons. org/licenses/by/2.0) which permits unrestricted use, distribution and reproduction in any medium, provided the work is properly cited.
Experiments on Animals (CPCSEA), India. All rabbits were procured from CPCSEA approved breeding facility and were housed individually in stainless steel cages in air conditioned rooms at $20 \pm 3{ }^{\circ} \mathrm{C}$ and relative humidity of 30 to $70 \%$, with $12 \mathrm{~h}$ artificial light and 12 $\mathrm{h}$ dark. The air changes in the experimental rooms were minimum 15 per hour. Standard food pellets and clean filtered water were provided to the rabbits ad libitum throughout the duration of experiment.

These animals appeared normal without any clinical expression during life-phase part of the study. On termination of the life-phase of the study, these animals were received at Pathology section for routine post mortem examination.

The animals were euthanized by carbon dioxide asphyxiation prior to conducting routine necropsy. External as well as internal examination of the carcasses did not reveal any abnormality of pathological significance. Grossly, the pancreas which is of mesenteric type (diffusely distributed in the mesentery of small bowel) in rabbits, appeared normal. All the required organs including pancreas as per the study protocol were collected and preserved in 10\% neutral buffered formalin for fixation. The fixed morbid tissues were processed routinely to have $\mathrm{H} \& \mathrm{E}$ stained microsections ( $5 \mu$ thick) for histopathological evaluation.

\section{Results}

Out of 144 rabbits examined, ectopic splenic tissue was microscopically recorded in pancreas of five animals (males-2, females-3) showing occurrence rate of $3.47 \%$. In four cases, the ectopic splenic tissue was devoid of any fibrous capsule and was closely embedded in the pancreatic parenchyma (Fig. 1, 2). In fifth one, the splenic tissue was loosely attached to pancreatic margin, surrounded by a thin delicate capsule (Fig. 3, 4) and was comparable to previous 

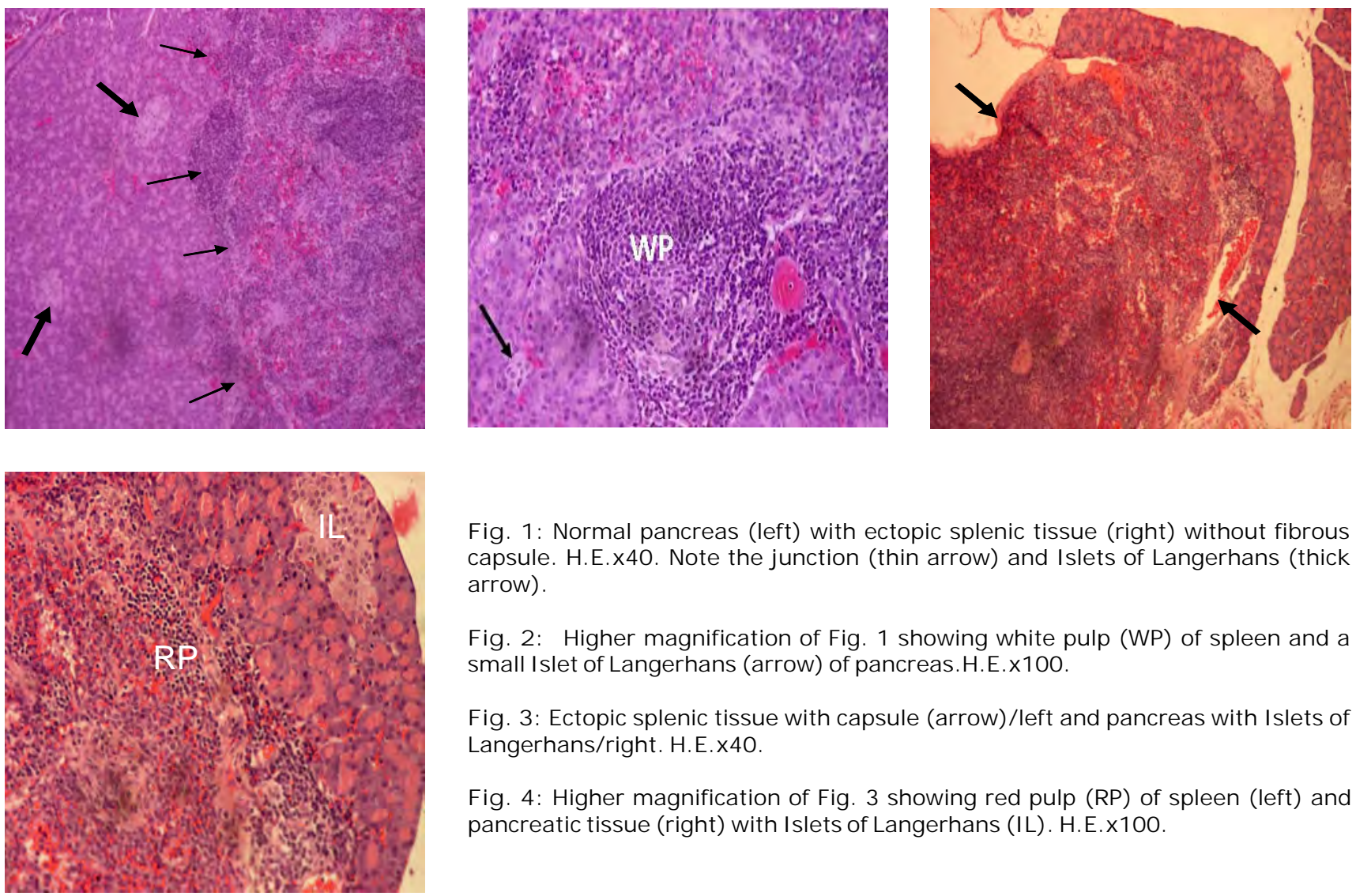

Fig. 1: Normal pancreas (left) with ectopic splenic tissue (right) without fibrous capsule. H.E.x40. Note the junction (thin arrow) and Islets of Langerhans (thick arrow).

Fig. 2: Higher magnification of Fig. 1 showing white pulp (WP) of spleen and a small I slet of Langerhans (arrow) of pancreas. H.E.x100.

Fig. 3: Ectopic splenic tissue with capsule (arrow)/left and pancreas with I slets of Langerhans/right. H.E.x40.

Fig. 4: Higher magnification of Fig. 3 showing red pulp (RP) of spleen (left) and pancreatic tissue (right) with I slets of Langerhans (IL). H.E.x100.

observation [3]. The ectopic splenic tissue did not reveal any notable change and appeared normal maintaining its usual histological architecture i.e. red pulp, white pulp (periarteriolar lymphoid sheath PALS), marginal zone and a few scattered fibrous trabeculae. Further, evidence of any compression at the junction of pancreatic - splenic tissues could not be observed in any case. Microscopically, the pancreas also appeared normal with scattered islets of Langerhans which consisted of closely apposed branching cords of pale staining polygonal cells surrounded by basal lamina. However, the part of pancreatic parenchyma having ectopic splenic mass contained less number of islets in comparison to other areas, the reason of which was uncertain.

\section{Discussion}

There is every likelyhood that during organogenesis/remodeling stages in intrauterine life, at times a pinch of tissue of one organ is transported/ transplanted to other adjoining organs and start growing there, finally developing into 'ectopic tissue'. Recently, a solitary case of ectopic spleen was recorded microscopically in the pancreas of an 8-months old New Zealand White rabbit [3]. In past, nine cases (males-1/24, female-8/24) of ectopic foci of splenic tissue were reported in Himalayan rabbits (18.75\%)[6].

In human beings, intrapancreatic accessory spleens have been reported in about 15-30 \% during abdominal ultrasonography and unselected autopsies and ranged in size from a few millimeters to several centimeters, either single or multiple in numbers $[5,7$, $8,9]$. Thus, the rate of occurrence of intrapancreatic ectopic splenic tissue was quite high in comparison to our report. Analysis of several inbred strains of rabbits with high (30-50\%) frequencies of accessory spleens revealed that hereditary haematological diseases, autoimmune haemolytic anaemia and lymphosarcoma were associated with some of these conditions [10]. Del Chiaro et al. [4] and Schreiner et al. [11] opined that ectopic intrapancreatic splenic tissues are usually detected incidentally as hypervascular solid nodules and might be misdiagnosed as neuroendocrine tumours. In the present study, the pancreas grossly appeared normal in all the five cases. These cases were considered incidental in nature and congenital in origin supporting the views of earlier workers $[3,6]$.

\section{Acknowledgements}

Authors are thankful to Dr. Kevin Isaacs, Independent Consultant in Toxicologic Pathology, UK for his valuable contributions in histopathological interpretation and to the Managements of Jai Research Foundation for providing necessary facilities and grant of permission to publish the findings.

\section{Competing interests}

Authors declare that they have no competing interest.

\section{References}

1. Damjanov I. (1988) Genetic and System Diseases. In: Pathology/Eds. Rubin E. and Farber, JL. J. B. Lippincott Co. Philadelphia, London, Mexico, New work. 196-249. 
2. Eustis S. L., Boorman G. A., Harada T. and Popp J. A. (1990) Exocrine pancreas. In: Pathology of the Fischer Rat: Reference and Atlas / Eds. Boorman G. A., Eustis S. L., Elwell M. R. Montgomery Jr. C. A. and MacKenzie W. F. Academic Press, Harcourt Brace Jovanovich Publishers San Diego, New York, Boston, London, Sydney Tokyo, Toronto. 95-107.

3. Jose J. (2011) Ectopic Spleen in the Pancreas of a New Zealand White Rabbit. Toxpath Newsletter, STP-I, 4(2): 3-4.

4. Del Chiaro M., Bogazzi F., D'Imporzano S., Manetti L., Croce C., Perrone V. G., De Lio N., Boggi U., Martino E. and Mosca F. (2007) Ectopic spleens in the tail of the pancreas mimicking multifocal neuroendocrine tumors in a patient with history of endocrine neoplasia - A case report. $J$ Pancreas, 8:855-856.

5. Guo W., Han W., Liu J., Jin L., Li J. S. Zhang Z. T., and Wang Y. (2009) Intrapancreatic accessory spleen: A case report and review of the literature. World J Gastroenterol., 15 (9): 11411143.

6. Harleman J. H. (1983). Ectopic spleen tissue in the pancreas of Himalayan rabbits. Lab Animal Sci., 33(5): 463-464.
7. Federle M. P. (1992) The Spleen. In: Moss A. A. Gamsu G., Genant H. K., eds. Computed tomography of the body with magnetic resonance imaging. 2nd edn. Philadelphia, Pa: Saunders,: 1059-1090.

8. Furukawa H., Kosuge T., Kanai Y. and Mukai K. (1998) Epidermoid cyst in an intrapancreatic accessory spleen: CT and pathologic findings. Am. J Roentgenol, 171: 217.

9. Harris G. N. Kase D. J. Bradnock H. and Mckinley M. J. (1994) Accessory spleen causing a mass in the tail of the pancreas: MR imaging findings. Am. J Roentgenol., 163: $1120-1121$.

10. Wkisbroth S. H. Fox R. R., Scher S. and Crary D. D. (2005) Accessory spleens in domestic rabbits (Oryctolagus cuniculus). II. Increased frequency in haematological diseases and experimental induction with phenylhydrazine. Published online. Teratology, 13 (3): 253-262.

11. Schreiner A. M., Mansoor A., Faigel D. O. and Morgan T. K. (2008) Intrapancreatic accessory spleen: mimic of pancreatic endocrine tumour diagnosed by endoscopic ultrasound-guided fine-needle aspiration biopsy. Diagn. Cytopathol., 36: 262-265.

$* * * * * * * *$ 